\title{
Research on Incentive and restraint mechanism of capital operation of power grid enterprises under new development pattern
}

\author{
Lifang Zou ${ }^{1}$ Ling Lin $^{2}$ Meifeng Ke ${ }^{1}$ Chenhong Zheng ${ }^{1}$ Shiming Zhang ${ }^{1}$ Minquan $\mathrm{Ye}^{1}$ \\ ${ }^{1}$ Research Institute of Economics and Technology, State Grid Fujian Electric Power Co., Ltd, CHINA \\ ${ }^{2}$ State Grid Fujian Electric Power Co., Ltd, CHINA
}

\begin{abstract}
Under the new development pattern of dual circulation economy, the reform of state-owned enterprises has entered the deep water area, and the operating environment of power grid enterprises has changed significantly, which has a profound impact on the capital operation strategy and effect of the enterprises. This paper analyzes the new characteristics of capital operation of power grid enterprises under the new development pattern, constructs the incentive and restriction index system of capital operation of power grid enterprises, designs the incentive and restraint mechanism of capital operation of power grid enterprises, and verifies the scientificity and applicability of the mechanism by financial evaluation and analysis. The research results enrich the theory of capital operation management based on financial evaluation, and provide theoretical basis and practical reference for grid enterprises to optimize the distribution of capital investment and improve the efficiency of capital operation.
\end{abstract}

\section{The influence of new development pattern on capital operation of power grid enterprises}

In recent years, the world economy has faced severe challenges, such as the rise of unilateralism and trade protectionism, obvious anti-globalization trend and intensified international friction, which leads to the decline of international demand, the obstruction of international industrial chain and supply chain, and the weakening of the driving force of the international economic cycle. Since 2020, the novel coronavirus pneumonia outbreak in the world has been seriously affected by the epidemic in most countries and regions, and the global economy has experienced a serious recession. The outbreak of COVID-19 has further worsened the external environment of China's development, the external demand has shrunk dramatically, and the international external circle has been seriously impacted. Faced with severe and novel coronavirus pneumonia and severe domestic and international situation, the Central Committee proposed to accelerate the construction of a new development pattern with the main domestic cycle as the main body and the domestic and international dual circulation as the basis for mutual promotion. This is based on the major strategic decisions made at home and abroad in the current and future periods.

The impact of the new development pattern on the capital operation of power grid enterprises is mainly reflected in two aspects: first, the business competition environment of power grid enterprises is more complex under the reform of power system. The capital operation strategy of enterprises should adapt to the increasingly competitive market environment, expand business chain and promote the development of multiple businesses ${ }^{[1]}$. Second, the reform of state-owned enterprises has entered the deep water area, which puts forward new requirements for the capital structure, capital distribution and capital operation efficiency of power grid enterprises $^{[2]}$.

A new round of power system reform has changed the profit model of power grid enterprises. At the same time, with the access of micro grid, distributed generation, energy storage devices, and the maturity of power direct trading market, the whole power system will be reconstructed. It is no longer a simple power generation, transmission, transformation, distribution and consumption system. There may be distribution-use system, use-use system and other systems, which is of great significance to power grid enterprises The capital operation ability of the industry has put forward higher requirements. It is not only necessary to rely on the basic power transmission and distribution business to obtain income, but also need to carry out innovative additional value-added services, and improve the profit model and way of the company's capital operation. Therefore, we should formulate the power grid capital operation strategy under the environment of institutional change, so as to optimize the integration of internal resources and resource allocation, and enhance the company's marketoriented competitiveness and lean operation ability ${ }^{[4]}$. 
The deepening of the reform of state-owned enterprises has had a significant impact on the production and operation of power grid enterprises, mainly reflected in: first, in the enterprise management level, grid enterprises pay more attention to the efficiency and efficiency of capital operation, and the precise investment and lean asset management of power grid will become an important factor for the capital investment decision-making of power grid enterprises; second, at the organizational structure level of enterprises On the one hand, the grid enterprises will continuously clarify the asset interface, realize the effective separation of assets, and thus change the organizational structure of the enterprise $\mathrm{e}^{[5]}$.

\section{Construction of incentive and restraint index system for capital operation of power grid enterprises}

The new development pattern has a significant impact on the capital operation mode of power grid enterprises. Under this background, the incentive and restriction of capital operation of power grid enterprises is the key path to optimize the capital distribution of power grid enterprises and improve the efficiency of capital operation of power grid enterprises. The constraint refers to the initial selection stage before the feasibility study of capital investment projects ${ }^{[6]}$.

Based on the independent, objective and scientific evaluation principle, this paper constructs the operation incentive and constraint index system for the capital investment project of power grid enterprises, which is divided into basic financial indicators and sustainable development indicators, including five dimensions: capital structure, profitability, solvency, development ability and service capability ${ }^{[7]}$, as shown in table 1 .

Table 1. Incentive and constraint index system for capital operation of power grid enterprises

\begin{tabular}{|c|c|c|}
\hline $\begin{array}{c}\text { Serial } \\
\text { number }\end{array}$ & $\begin{array}{c}\text { Evaluation } \\
\text { dimension }\end{array}$ & Evaluating indicator \\
\hline 1 & \multicolumn{2}{|c|}{ Basic financial indicators } \\
\hline$(1)$ & $\begin{array}{c}\text { Capital } \\
\text { structure }\end{array}$ & Capital ratio \\
\hline \multirow{2}{*}{$(2)$} & Profitability & Internal rate of return \\
\cline { 3 - 3 } & & Financial net present value \\
\hline$(3)$ & Solvency & Payback period \\
\hline 2 & \multicolumn{2}{|c|}{ Sustainable levelopment indicators } \\
\hline \multirow{2}{*}{$(4)$} & \multirow{2}{*}{$\begin{array}{c}\text { Development } \\
\text { capacity }\end{array}$} & $\begin{array}{c}\text { Level of scientific and } \\
\text { technological research and } \\
\text { development }\end{array}$ \\
\cline { 3 - 3 } & \multicolumn{2}{|c|}{$\begin{array}{c}\text { Level of energy } \\
\text { conservation and emission } \\
\text { reduction }\end{array}$} \\
\hline
\end{tabular}

The basic financial indicators evaluate the economic performance of equity investment projects through quantitative financial indicators, mainly investigate the fund structure, profitability, investment recovery capacity and repayment ability of the project, so as to select projects with high economic value creativity.

Sustainable development indicators include development capacity and service capacity, mainly from market share, scientific and technological research and development level, energy conservation and emission reduction level to evaluate the sustainable development of projects ${ }^{[3]}$. This indicator shows the inclusiveness of the incentive and restraint mechanism ${ }^{[8]}$.

\section{(1) Capital structure}

The proportion of capital refers to the proportion of project capital and project debt fund. On the premise of meeting the relevant national regulations, it is an ideal ratio of capital and debt capital to meet the requirements of expected return on investment of equity investors and to prevent financial risks better.

(2) Profitability

(1) Internal return (IRR) refers to the discount rate when the present value of net cash flow in each year of the project calculation period is accumulated to zero, reflecting the profitability of all investment in the set calculation period. The calculation formula is as follows:

$$
\sum_{t=0}^{n}(C I-C O) t(1+I R R)^{-t}=0
$$

Among them, $C I$ is the cash inflow; $C O$ is the cash outflow; $(C I-C O)_{t}$ is the net cash flow of year $t$; and $n$ is the number of years in the calculation period.

(2) Financial net present value (NPV) refers to the sum of the present value of net cash flow in the calculation period of the project according to the benchmark rate of return of the relevant industry. The calculation formula is as follows:

$$
N P V=\sum_{t=0}^{\mathrm{n}}(C I-C O)_{t}\left(1+i_{0}\right)^{-t}
$$

Among them, $C I$ is the amount of cash inflow; $C O$ is the amount of cash outflow; $i_{0}$ is the benchmark rate of return of related industries; $n$ is the number of years in the calculation period.

(3) Investment payback period refers to the year when the cumulative net cash flow of the project is equal to zero, that is, the year when the cumulative net cash flow changes from negative to positive. The calculation formula is as follows:

$$
\sum_{t=1}^{p_{t}}(C I-C O)_{\mathrm{t}}=0
$$

Among them, $(C I-C O)_{t}$ is the net cash flow of year $t ; n$ is the number of years in the calculation period.

(3) Solvency

Asset liability ratio refers to the ratio of total liabilities to total assets at the end of each period. The calculation formula is as follows:

$$
L O A R=\frac{T L}{A L} \times 100 \%
$$

$T L$ refers to the total liabilities at the end of the period and $A L$ refers to the total assets at the end of the period.

(4) Development capacity 
(1) Market share is also known as market share, including the quantity and quality of market share.

The quantity of market share refers to the proportion of the sales volume or sales volume of the products produced by the enterprise in the same kind of products in a certain period of time. The quality of market share refers to the customer satisfaction rate and customer loyalty rate.

(2) The level of scientific and technological research and development is an important indicator to measure the development capability of technological innovation, which is measured by the proportion of project research and development investment to the total investment.

(5) Service capability

Energy conservation and emission reduction level is to measure the impact of project construction on carbon dioxide emission reduction, and evaluate the energy conservation and emission reduction level of the project $^{[9]}$. The formula is as follows:

$$
L=P \times C_{\text {coal }} \times C_{\text {carbon }}
$$

Among them, $L$ is energy saving and emission reduction level; $P$ is power generation, $C_{c o a l}$ is standard coal coefficient, $C_{\text {carbon }}$ is standard carbon coefficient. The coefficient of standard coal is the amount of standard coal converted into standard coal per degree, and the standard coal folding coefficient is the content of carbon element converted into standard coal per kilogram.

\section{The constraint boundary of incentive and restraint mechanism of capital operation}

Based on the traditional financial evaluation model, this paper designs the evaluation standard of capital operation incentive and restraint mechanism in combination with the innovation of the company's current development pattern, so as to carry out the selection of capital investment projects. Among them, the economic nature of capital investment projects must meet the basic financial indicators or sustainable development indicators, otherwise, it will not be approved. See Table 2 for specific constraint boundary.

Table 2. Constraint boundary and basis of incentive and constraint indicators of capital operation

\begin{tabular}{|c|c|c|c|}
\hline $\begin{array}{c}\text { Serial } \\
\text { numbe } \\
\mathbf{r}\end{array}$ & $\begin{array}{c}\text { Evaluating } \\
\text { indicator }\end{array}$ & $\begin{array}{c}\text { Constraine } \\
\text { d boundary }\end{array}$ & \multicolumn{1}{|c|}{ Basis } \\
\hline 1 & $\begin{array}{l}\text { Basic financial indicators: must meet (1) (5) } \\
\text { at the same time }\end{array}$ \\
\hline$(1)$ & $\begin{array}{c}\text { Capital } \\
\text { ratio }\end{array}$ & $\begin{array}{l}\text { According to the } \\
\text { "Economic } \\
\text { evaluation methods } \\
\text { and parameters of } \\
\text { construction projects } \\
\text { (Third Edition)", the } \\
\text { capital ratio of }\end{array}$ \\
\hline
\end{tabular}

\begin{tabular}{|c|c|c|c|}
\hline & & & $\begin{array}{l}\text { projects in electric } \\
\text { power, mechanical } \\
\text { and electrical, } \\
\text { building materials, } \\
\text { chemical industry, } \\
\text { petroleum } \\
\text { processing, } \\
\text { nonferrous metals, } \\
\text { light industry, } \\
\text { textile, commerce } \\
\text { and other industries } \\
\text { is } 20 \% \text { or more. } \\
\end{array}$ \\
\hline (2) & $\begin{array}{c}\text { Financial } \\
\text { net } \\
\text { present } \\
\text { value }\end{array}$ & $>=0$ & $\begin{array}{l}\text { "Economic } \\
\text { evaluation methods } \\
\text { and parameters of } \\
\text { construction projects } \\
\text { (Third Edition)": } \\
\text { when the financial } \\
\text { net present value is } \\
\text { greater than or equal } \\
\text { to } 0 \text {, the project shall } \\
\text { be considered to be } \\
\text { accepted financially. }\end{array}$ \\
\hline (3) & $\begin{array}{c}\text { Payback } \\
\text { period }\end{array}$ & $\begin{array}{l}\text { Less than } \\
\text { operation } \\
\text { period }\end{array}$ & $\begin{array}{l}\text { "Economic } \\
\text { evaluation methods } \\
\text { and parameters of } \\
\text { construction projects } \\
\text { (Third Edition)": the } \\
\text { short payback period } \\
\text { of investment } \\
\text { indicates that the } \\
\text { project has fast } \\
\text { payback and strong } \\
\text { anti risk ability. } \\
\end{array}$ \\
\hline (4) & $\begin{array}{l}\text { Asset } \\
\text { liability } \\
\text { ratio }\end{array}$ & $<=65 \%$ & $\begin{array}{l}\text { "Interim Measures } \\
\text { for business } \\
\text { performance } \\
\text { assessment of } \\
\text { persons in charge of } \\
\text { central enterprises" } \\
\text { mentioned that the } \\
\text { enterprises whose } \\
\text { asset liability ratio is } \\
\text { controlled within a } \\
\text { reasonable range } \\
\text { and meet other } \\
\text { conditions will be } \\
\text { awarded the "special } \\
\text { award for } \\
\text { management } \\
\text { progress". }\end{array}$ \\
\hline \multirow{7}{*}{ (5) } & $\begin{array}{c}\text { Serial } \\
\text { number }\end{array}$ & $\begin{array}{l}\text { Project } \\
\text { category }\end{array}$ & $\begin{array}{c}\text { Internal rate of } \\
\text { return }\end{array}$ \\
\hline & (1) & $\begin{array}{l}\text { Energy } \\
\text { storage }\end{array}$ & $8 \%$ \\
\hline & (2) & $\begin{array}{l}\text { electric } \\
\text { vehicle }\end{array}$ & $9.8 \%$ \\
\hline & (3) & $\begin{array}{c}\text { Integrated } \\
\text { energy } \\
\text { services }\end{array}$ & $9 \%$ \\
\hline & (4) & $\begin{array}{l}\text { Energy } \\
\text { saving } \\
\text { service }\end{array}$ & $8.5 \%$ \\
\hline & (5) & $\begin{array}{l}\text { Photovoltai } \\
\text { c power } \\
\text { generation }\end{array}$ & $10.2 \%$ \\
\hline & (6) & $\begin{array}{l}\text { Wind } \\
\text { power }\end{array}$ & $8.5 \%$ \\
\hline
\end{tabular}




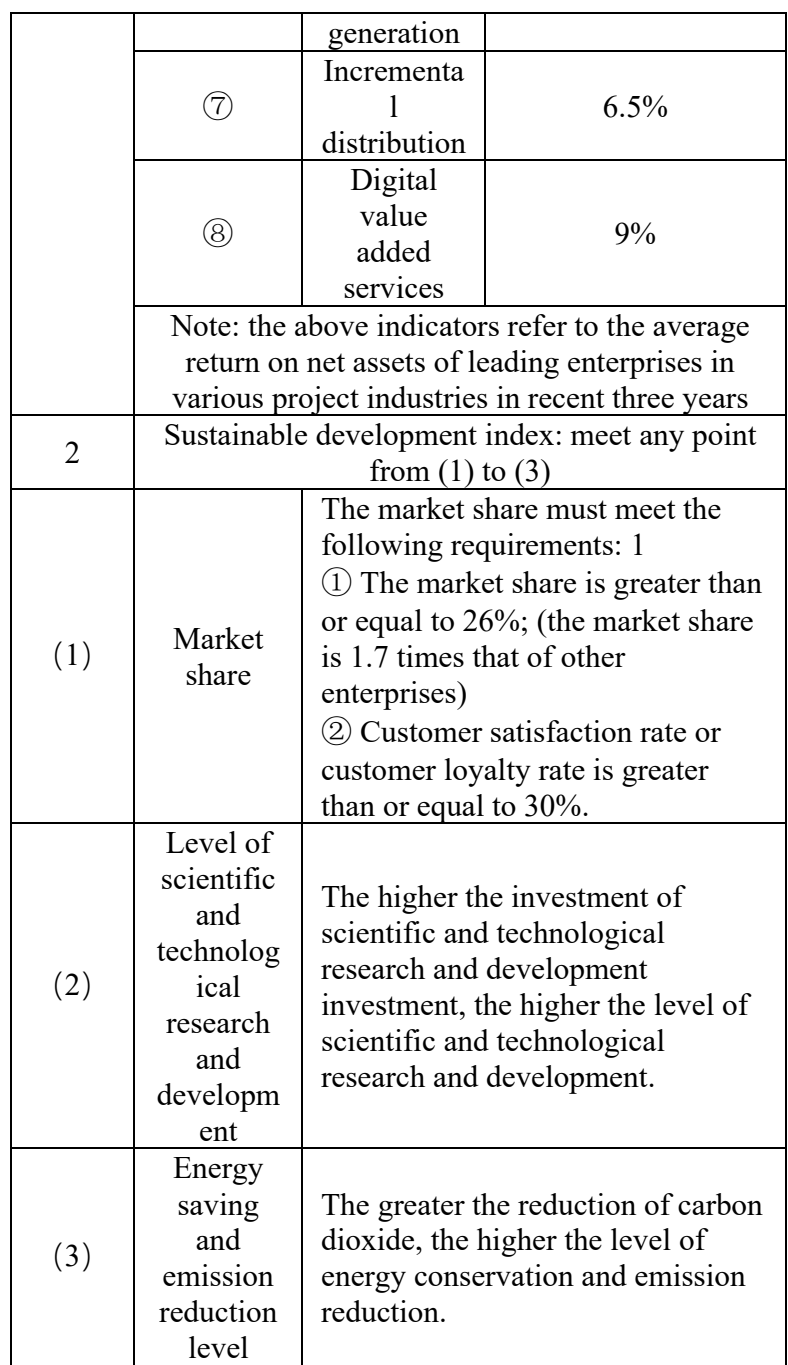

\section{Financial evaluation}

This paper takes the roof construction of a factory building in an industrial park as a case to make financial evaluation. The planned construction capacity of the project is 29.7 MW. The project adopts the mode of "Self use, surplus electricity online", and the roof construction of distributed photovoltaic is free of rent. The financial evaluation of the project is based on "About printing and distributing the economic evaluation methods and parameters of construction projects (Third Edition)" (fgtz [2006] No. 1325) issued by the National Development and Reform Commission, Ministry of construction and " "people's Republic of China power industry standard DL / t5438-2009 - economic evaluation principles for power transmission and transformation projects" issued by the National Energy Administration.

(1) Evaluation parameters:

1) Investment related parameters. The total investment (including working capital) to be constructed is 99.495 million yuan, and the capital account for $20 \%$ of the total construction investment. The current capital is estimated as 40 yuan $/ \mathrm{kW}$, and the proportion of its own working capital is $30 \%$. The annual interest rate of long-term loan is $4.9 \%$, and the repayment period is 15 years, and the repayment method of equal principal is adopted.

2) Cost related parameters.

The installed capacity of the project is $29.7 \mathrm{MW}$, with 6 months of construction period and 25 years of operation; material cost is listed as 6.5 yuan $/ \mathrm{kW} ; 4$ operation and maintenance personnel are paid at $70000 y u a n$ / year, and welfare premium is $55 \%$ of the salary; repair free in the first three years of operation period, and $0.5 \%$ of original value of fixed assets in the fourth-sixth year, $1.5 \%$ of original value of fixed assets in the seventh to 25 th years; $0.15 \%$ of the value of fixed assets. The depreciation life of the project is 15years, and the residual value rate is $5 \%$; other expenses of the project are set to be 42 yuan / $\mathrm{kW}$.

3) Revenue related parameters

Power generation. According to the load consumption of the enterprises in the industrial park in recent years, $49 \%$ of the power generation of the project is self-use, $51 \%$ is online, and the average annual power generation is 27.522 million $\mathrm{kWh}$. The first year attenuation of single silicon components shall not exceed $2 \%$, and the annual attenuation from the second year to the 15 th year shall not exceed $0.45 \%$ each year.

Electricity price. The on grid price of the project is calculated according to the benchmark price of coal-fired units of 0.3932 yuan; the spontaneous self-use price is calculated at $9 \%$ discount of the local industrial and commercial sales price (peak: 0.6 yuan / kWh, 0.5369 yuan / $\mathrm{kWh}$, valley 0.435054 yuan / $\mathrm{kWh}$ ); financial evaluation is conducted according to the comprehensive price of 0.4481 yuan / $\mathrm{kWh}$, and photovoltaic subsidy is not considered in this evaluation.

(4) Tax related parameters

The VAT rate is $13 \%$; the urban maintenance and construction tax and education surcharge with business tax surtax are 5\% and 5\% respectively. The first-third year of income tax is exempt from enterprise income tax, and the enterprise income tax will be reduced by half in the fourth to sixth years. From year 7 , the tax rate is drawn at $25 \%$.

(2) Evaluation results

According to the calculation, the internal rate of return of the project is $12.54 \%$, which is greater than $10.2 \%$ of the incentive and restraint mechanism of photovoltaic project; the net present value is 22.2627 million yuan, which is greater than 0 ; the investment recovery period is 10.44 years, and the project has certain economic benefits and is feasible financially in the interval of 7-15 years. The specific financial evaluation results are shown in Table 3.

Table 3. List of financial evaluation results

\begin{tabular}{|c|c|c|c|}
\hline $\begin{array}{c}\text { Serial } \\
\text { number }\end{array}$ & Evaluation parameters & Unit & Evaluation results \\
\hline 1 & Internal rate of return & $\%$ & 12.54 \\
\hline 2 & net present value & $\begin{array}{c}\text { Ten } \\
\text { thousand } \\
\text { yuan }\end{array}$ & 2262.27 \\
\hline 3 & Payback period & Year & 10 \\
\hline
\end{tabular}




\begin{tabular}{|c|c|c|c|}
\hline 4 & $\begin{array}{c}\text { Asset liability ratio (average } \\
\text { annual) }\end{array}$ & $\%$ & 62 \\
\hline
\end{tabular}

(3) Sensitivity analysis

It is estimated that the project is the most sensitive to electricity price income, followed by construction investment, and finally the operating cost. It is suggested to carefully prevent the impact of sensitive factors of electricity price and power generation on the project yield. As shown in Table 4 and Figure 1

Table 4. Details of sensitivity analysis

\begin{tabular}{|c|c|c|c|c|c|}
\hline \multicolumn{6}{|c|}{1 Construction investment } \\
\hline $\begin{array}{l}\text { Rate of } \\
\text { change }\end{array}$ & $-10 \%$ & $-5 \%$ & 0 & $+5 \%$ & $+10 \%$ \\
\hline $\begin{array}{l}\text { Internal } \\
\text { rate of } \\
\text { return }\end{array}$ & $16.96 \%$ & $14.58 \%$ & 12.54 & $10.78 \%$ & $9.24 \%$ \\
\hline $\begin{array}{c}\text { Payback } \\
\text { period } \\
\text { (year) }\end{array}$ & 6 & 8 & 10 & 12 & 16 \\
\hline \multicolumn{6}{|c|}{2 Electricity price revenue } \\
\hline $\begin{array}{l}\text { Rate of } \\
\text { change }\end{array}$ & $-10 \%$ & $-5 \%$ & 0 & $+5 \%$ & $+10 \%$ \\
\hline $\begin{array}{l}\text { Internal } \\
\text { rate of } \\
\text { return }\end{array}$ & $8.18 \%$ & $10.29 \%$ & $12.54 \%$ & $14.95 \%$ & $17.52 \%$ \\
\hline $\begin{array}{c}\text { Payback } \\
\text { period } \\
\text { (year) }\end{array}$ & 16 & 13 & 10 & 7 & 6 \\
\hline \multicolumn{6}{|c|}{3 Operating costs } \\
\hline $\begin{array}{l}\text { Rate of } \\
\text { change }\end{array}$ & $-10 \%$ & $-5 \%$ & 0 & $+5 \%$ & $+10 \%$ \\
\hline $\begin{array}{l}\text { Internal } \\
\text { rate of } \\
\text { return }\end{array}$ & $13.47 \%$ & $13.01 \%$ & $12.54 \%$ & $12.08 \%$ & $11.61 \%$ \\
\hline $\begin{array}{c}\text { Payback } \\
\text { period } \\
\text { (year) }\end{array}$ & 9 & 9 & 10 & 10 & 11 \\
\hline
\end{tabular}

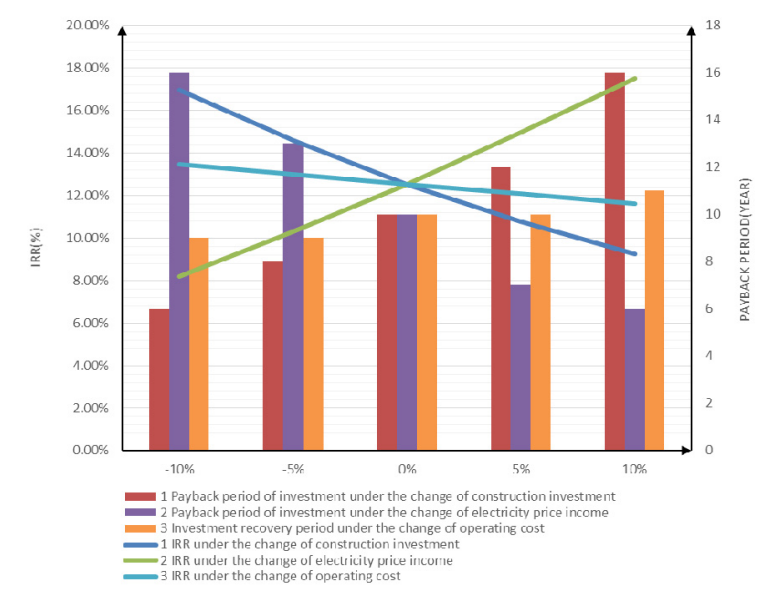

Figure 1. Project sensitivity analysis

\section{Conclusion}

The research on Incentive and restraint mechanism of capital operation is the front link of capital investment project selection, the further deepening of closed-loop control of the whole process of capital, and is conducive to the optimization and improvement of capital layout and operation efficiency. The capital operation incentive and constraint index system and mechanism constructed in this paper are closely around the industrial chain of power grid enterprises to expand market-oriented business. Guided by benefit and value creation, it can guide power grid capital to flow to the value highland, actively and orderly expand upstream and downstream business, enhance market competitiveness and value creativity of power grid enterprises, and promote highquality power grid enterprises at a deeper and higher level development.

\section{References}

1. C.Jiying, Y.Yuqi, S.Wentao, Capital Modern commerce and trade industry, 42, 91-92 (2021)

2. W.Zhijuan. Research on the performance evaluation of state-owned enterprises based on the combination of EVA and non-financial indicators (Anhui, Hefei University of Technology,2012)

3. X.Anbo. State owned capital investment and operation companies should speed up the overall transformation and capability improvement (China economic times, 2021)

4. Z.Jinsheng, Y.Guoqiang, W.Peng. Friends of accounting, 36, 6-8 (2011)

5. W.Guohao. Research on the performance evaluation index system of Sinopec -- Based on the concept of comprehensive income (Tianjin, Tianjin University of Finance and Economics, 2015)

6. L.Tao, W.Gang, G.Hongze, et al. China management informatization, 23,124-125 (2020)

7. L.yinghan. China management informatization, 23,28-29 (2020)

8. Z.Jiacheng, R.Boqiang, Y.Ben, W.Zhongrong. Resource conservation and environmental protection, 10, 53 (2019)

9. Z.Nansong, X.Chunqing, J.Yunxin, Green environmental protection building materials, 02, 5354 (2021) 